\title{
ANTIMICROBIAL ACTIVITY OF DIFFERENT DENTAL CEMENTS ON AGGREGATIBACTER ACTINOMYCETEMCOMITANS
}

\section{ATIVIDADE ANTIMICROBIANA DE DIFERENTES CIMENTOS ODONTOLÓGICOS SOBRE AGGREGATIBACTER ACTINOMYCETEMCOMITANS}

\author{
Thalyta Brito Santos Lima* \\ Isabela Nunes Souza** \\ Raquel Santos de Oliveira*** \\ João Milton Rocha Gusmão*... \\ Isabel Celeste Caires Pereira Gusmão \\ Alberto N. G. Antunes*****
}

\section{ABSTRACT}

\begin{abstract}
Objectives: The objective of this study was to evaluate, in vitro, the possible antimicrobial activity against the $A$ actinomycetemcomytans of three dental cements: glass-ionomer cement, zinc phosphate cement and resin cement. Material and Methods: Strains of A actinomycetemcomitans ATCC 29522 were used. The microorganism was grown in $\mathrm{BHI}$ Agar and transferred to tubes containing sterile saline solution. The suspension was calibrated to a similar turbidity to the 0.5 tube from McFarland scale. A base layer consisting of $20 \mathrm{ml}$ of BHI agar was placed in sterile Petri $90 \times 15 \mathrm{~mm}$ plates. After solidification, was added 0,1 uL of microbial suspension, and three wells with $6 \mathrm{~mm}$ in diameter and $1 \mathrm{~mm}$ deep were made, the wells were filled with cements with zinc phosphate cement, glass-ionomer cement and resin cement indicated for permanent cementation for fixed prostheses immediately after handling and positive (chlorhexidine) and negative (saline) controls. Results: After 48 hours the presence or absence of inhibition halo of microbial growth was analyzed around the specimens. Conclusion: Zinc phosphate cement and glass ionomer cement tested showed antibacterial activity against $A$ actinomycetemcomitans unlike resin cement.
\end{abstract}

Descriptors: Periodontium • Dental Cements • Periodontal Diseases

\section{RESUMO}

O objetivo deste estudo foi avaliar in vitro a ação antibacteriana de três cimentos odontológicos utilizados para fixação de próteses fixas: ionômero de vidro (Vitro CemR), fosfato de zinco (Cimento LSR) e cimento resinoso (Dual CementR) ao microrganismo Aggregatibacter actinomycetemcomitans ATCC 29522. A espécie foi ajustada a 0,5 de MacFarland. Foi realizado o teste de difusão em ágar em triplicata, em meio BHI onde 0,1 $\mu \mathrm{L}$ foi semeado por placa. Um corpo de prova em formato de disco de cada material foi colocado em poços de $6 \mathrm{~mm}$ de profundidade. Como controles positivo e negativo foram utilizados clorexidina e soro fisiológico respectivamente. Após a distribuição dos corpos de prova, as placas foram incubadas a $37^{\circ} \mathrm{C}$ por 48 horas. $\mathrm{O}$ halo de inibição formado foi mensurado. O cimento resinoso não apresentou atividade antibacteriana, diferentemente do fosfato de zinco e ionômero de vidro, que apresentaram positividade em todas as amostras, havendo diferença entre eles com o fosfato de zinco apresentando maior atividade. Cimentos de fosfato de zinco e ionômero de vidro possuem atividade antimicrobiana, diferentemente dos cimentos resinosos.

Descritores: Periodonto • Cimentos Dentários • Doenças Periodontais

\footnotetext{
* Acadêmica de Odontologia. Thalytabrito.nutri@gmail.com

** Acadêmica de Odontologia. bellinha944@gmail.com

*** Acadêmica de Odontologia. Santolli.raquel@gmail.com

**** Mestre em Prótese Dentária. joao.milton@ig.com.br

***** Mestre em Microbiologia. gusmao.isabel@yahoo.com.br

****** Doutor em Odontologia. antunes1978@gmail.com
} 


\section{INTRODUCTION}

The teeth loss in adults is strongly associated with the periodontal disease which is the leading cause of teeth loss ${ }^{1}$. It consists of a chronic inflammatory process resulting in the loss of the tooth support.

Aggressive periodontitis consists of a rare type of periodontal disease; it affects approximately $1 \%$ of the adult population. The patient presents rapid loss of periodontal attachment and severe destruction of the alveolar bone. On clinical examination it is observed that the amount of biofilm is not proportional to the destruction degree of periodontal tissues, but there is a direct relation with the founded amount of Aggregatibacter actinomycetemcomitans 2-10.

Microbiological and host factors are determinants of pathogenicity of the microorganism. The colonization by $A$ actinomycetemcomytans is facilitated by several factors of virulence, facilitators of colonization, invasion and destruction of periodontal tissues ${ }^{3,5,6}$.

Patients who are conventional fixed prostheses users present an additional risk to the colonization by periodontopathogenic microorganisms, which is the union interface between the prosthesis and the teeth. Different cements are used for the union of the prostheses to the teeth ${ }^{11}$.

The objective of this study was to evaluate, in vitro, the possible antimicrobial activity against the $A$ actinomycetemcomytans of three dental cements: glass-ionomer cement, zinc phosphate cement and resin cement.

\section{METHODS}

\section{Microorganisms Reactivation}

Strains of $A$ actinomycetemcomitans ATCC 29522 were used. The microorganisms were obtained on the Reference Materials Laboratory of the National Institute for Quality Control in Health (Oswaldo Cruz Foundation - Fiocruz, Rio de Janeiro, RJ, Brazil). The reactivation was performed in heart and brain infusion broth - BHI (DIFCO, Detroit, Michigan, USA) at $37^{\circ} \mathrm{C}$. Microorganism suspensions were prepared in saline solution, under 1.5106 $\mathrm{ml} \mathrm{microorganism}^{-1}$ concentration, consis- tent with the MacFarland scale.

The microorganism was grown in $\mathrm{BHI}$ Agar (Difcoß, Detroit, Michigan, USA) at $37^{\circ} \mathrm{C}$ for $48 \mathrm{~h}$. After growing, the microorganism was removed from the surface of the plaques with the sterile swabs help, and transferred to tubes containing sterile saline solution. The suspension was calibrated to a similar turbidity to the 0.5 tube from McFarland scale, which corresponds to $10^{6}$ cells $/ \mathrm{ml}$; proven by the reading through spectrophotometer (Micronal $S / A$ - São Paulo, SP, Brazil).

\section{Antimicrobial Activity Analysis}

A base layer consisting of $20 \mathrm{ml}$ of $\mathrm{BHI}$ agar (Difco, Detroit, USA) was placed in sterile Petri $90 \times 15 \mathrm{~mm}$ plates. After solidification, was added $0,1 \mathrm{uL}$ of microbial suspension, and three wells with $6 \mathrm{~mm}$ in diameter and $1 \mathrm{~mm}$ deep (one for each material) were made by removing agar in equidistant points, using sterile instruments.

The wells were filled with cements with zinc phosphate cement, glass-ionomer cement and resin cement indicated for permanent cementation for fixed prostheses immediately after handling and positive (chlorhexidine) and negative (saline) controls.

The Petri plaques were taken to a bacteriological incubator at $37^{\circ} \mathrm{C}$ under microaerophilic conditions. After 48 hours the presence or absence of inhibition halo of microbial growth was analyzed around the specimens. When present, its diameter was measured with good lighting conditions, with the aid of an electronic digital caliper Stainless Steel - Digimess ${ }^{\circledR}$, Hong Kong, China). In positive and negative controls the presence or absence of microbial growth was analyzed.

\section{Statistical analysis}

Kolmogorov-Smirnov test demonstrated that the data of the variable "inhibiting halo" showed normal distribution.

ANOVA test one criterion, followed by the post hoc Tukey test, was used to evaluate the existence of differences in the variable "inhibition halo" between each one of the evaluated cements: zinc phosphate cement(C1), glass ionomer cement (C2) and resin cement $(\mathrm{C} 3)$.

The significance level was set at 5\%.
LIMA, TBS

SOUZA, IN

OLIVEIRA RS

GUSMÃO, JMR

GUSMÃO, ICCP

ANTUNES, ANG

ANTIMICROBIAL ACTIVITY OF DIFFERENT DENTAL CEMENTS ON AGGREGATIBACTER ACTINOMYCETEMCOMITANS
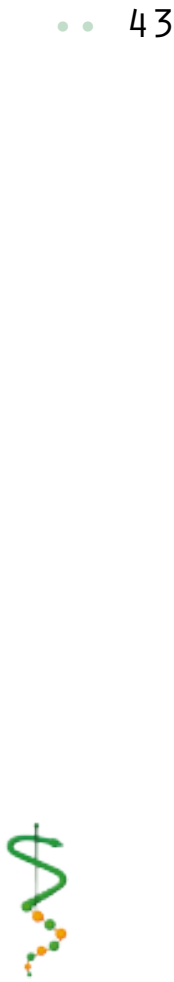

Rev. OdOnTOL.

UNIV. CID, SÃo PAulo

2016; 29(1): 42-7. JAN-ABR 
LIMA, TBS

SOUZA, IN

OLIVEIRA RS

GUSMÃO, JMR

GUSMÃO, ICCP

ANTUNES, ANG

ANTIMICROBIAL ACTIVITY OF DIFFERENT

DENTAL CEMENTS ON AGGREGATIBACTER ACTINOMYCETEMCOMITANS
The analyses were performed using GraphPad Prism 1.5 software (San Diego, CA, USA).

\section{RESULTS}

The Table 1 presents the inhibition halo formed for the tested cements as well as for positive and negative controls.

ANOVA test one criterion showed the presence of difference in the "inhibiting halo" variable between the cements. D'agostinho Tukey \& Pearson test showed that "inhibiting halo" was: higher in $\mathrm{C} 1$ when compared to C2 $(p<0.05)$, and C3 ( $p<0.05)$; higher in $\mathrm{C} 2$ when compared to C3 (resin cement) $(p<0.05)$.

\section{DISCUSSION}

The periodontal insertion loss has been responsible for the early loss of teeth in a significant range of the population(10). Several microorganisms participate in the etiology of the periodontal disease $\mathrm{e}^{11-14}$. Prevention methods need to be widely used aiming to control this disease, as offering orientation and oral hygiene prac-

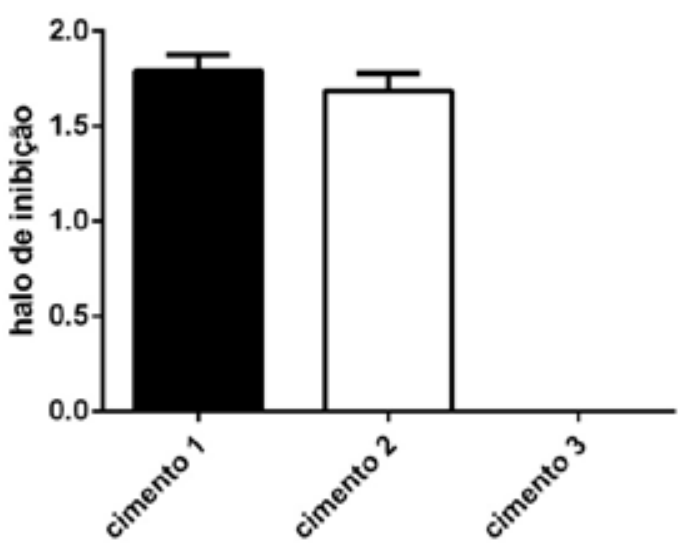

Table 1 - Mean, standard deviation and comparison between value groups of the variable "inhibiting halo".

* P value obtained by ANOVA one criterion followed by the post hoc Tukey.

\section{${ }^{1} \mathrm{C} 1$ versus $\mathrm{C} 2$}

${ }^{2} \mathrm{C} 1$ versus $\mathrm{C} 3$

${ }^{3} \mathrm{C} 2$ versus $\mathrm{C} 3$

Figure 1 - Mean and standard deviation of the variable values "inhibiting halo" 
tices $^{12}$, and the use of specific antimicrobials.

In the classification of the periodontal diseases, the aggressive periodontitis is characterized by a rapid insertion loss in patients that do not present a biofilm compatible with the evolution of the disease, and that present themselves without systemic changes ${ }^{15}$.

$A$ actinomicetemcomitans participates in the etiology of the periodontitis agressiva ${ }^{5}$, so the control of this microorganism becomes fundamental in the prevention and treatment of this disease.

The restoration and the maintenance of the periodontal health are fundamental to obtain success in fixed prosthe$\operatorname{ses}^{11}$. The use of fixed prostheses on natural teeth presents a space between the tooth and the prosthesis that is filled with cement and is called cementation line. This space is externalized in the cervical margins of the crowns, usually extending subgingivally to a $0.5 \mathrm{~mm}$ limit. The searching for the best possible adaptation has always been the goal for prosthodontists, as through that space bacterial infiltration can occur, causing decay and the periodontal disease.

Dental cements can actively participate in the prevention of periodontal disease by presenting antimicrobial activity. The results of this study were very useful from a scientific point of view, given that they show statistically significant values for the tested cements, with positivity zinc phosphate cement and glass ionomer cement and with negativity for the resin cement for antibacterial activity. The founded values corroborate to those from Kla1 et $a^{16}$ (2014) regarding the zinc phosphate cement and the resin cement, but not in relation to the glass ionomer cement.

In the present study, zinc phosphate cement presented the highest antibacterial activity among the tested cements. That activity is certainly due to the presence of oxides in the composition of this material. This characteristic can be an indication for the use of such material at with risk patients to the periodontal disease.

Although it is the most studied material among the tested sealers, the resin cement did not present antibacterial activity, which is in line with the other studies described in the literature ${ }^{17,18}$

The glass ionomer cement tested showed antibacterial activity against $A$ actinomycetemcomitans. This result is in accordance with the results from ${ }^{19}$.

This studie show positive antibacterial activity for glass ionomer cements, and attribute this activity to fluoride release. This release occurs both in fresh state and after the polimerization, being more significant in the fresh state.

The glass ionomer $\mathrm{pH}$ also favors the antibacterial activity of this material ${ }^{20}$. Authors present the results of studies that establish a correlation between low $\mathrm{pH}$ and fluoride release, that is, the lower the $\mathrm{pH}$, the lower the fluoride concentration needed to develop antibacterial activity ${ }^{20}$. In the current study the antibacterial action of the glass ionomer cement was satisfactory with respect to $A$ actinomycetemcomitans, what suggests that the use of cement, besides of the zinc phosphate cement, is also suitable for the cementation of fixed prostheses in patients with a history of periodontal disease.

The cements were evaluated in this study for a 48 hours period. Other studies with alternative methods, and for longer periods of time are needed to confirm the findings, however, the authors consider important the obtained results, because there were statistical differences between the tested cements with two materials presenting positive antimicrobial activity and one of them presenting negative activity, what makes this study important to be added to others in this important area of study of great clinical relevance in dental practice.

\section{CONCLUS ION}

Considering the limitations of this study, we concluded that zinc phosphate cement and glass ionomer cement tested showed antibacterial activity against $A$ actinomycetemcomitans unlike resin cement and zinc phosphate cement showed the highest antibacterial activity among the evaluated materials, being statistically superior to the others.
LIMA, TBS

SOUZA, IN

OLIVEIRA RS

GUSMÃO, JMR

GUSMÃO, ICCP

ANTUNES, ANG

ANTIMICROBIAL ACTIVITY OF DIFFERENT DENTAL CEMENTS ON AGGREGATIBACTER ACTINOMYCETEMCOMITANS

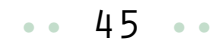

REV, ODONTOL.

UNIV, CID, SÃO PAULO

2016; 29(1): 42-7, JAN - ABR 
LIMA, TBS

SOUZA, IN

OLIVEIRA RS

GUSMÃO, JMR

GUSMÃO, ICCP

ANTUNES, ANG

ANTIMICROBIAL ACTIVITY OF DIFFERENT

DENTAL CEMENTS ON

AGGREGATIBACTER

ACTINOMYCETEMCOMITANS

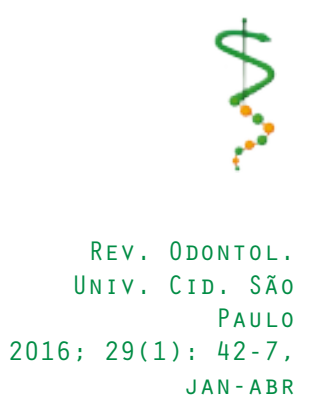

\section{REFERÊNCIAS}

1. Gasparetto A, Aarna-Chavez VE, Avila-Campos MJ. Aderência de Actinobacillus actinomycetemcomitans às células epiteliais bucais: estabilidade e aspectos ultra-estruturais. Pesquisa Odontológica Brasileira. 2000;14(4):311-8.

2. Nakagawa RI, Guazeli-Amin VH, Hidalgo MM, Trevisan Jr. W, Itano EN. Anticorpos antileucotoxina contra Actinobacillus actinomycetemcomitans em amostras de soro e saliva de pacientes com periodontite juvenil localizada. Pesquisa Odontológica Brasileira. 2001;15(1):05-11.

3. Tan KS, Song KP, Ong G. Cytolethal distending toxin of Actinobacillus actinomycetemcomitans. Occurrence and association with periodontal disease. Journal of periodontal research. 2002;37(4):268-72.

4. Van Hoogmoed CG, Geertsema-Doornbusch Gl, Teughels W, Quirynen M, Busscher HJ, Van der Mei HC. Reduction of periodontal pathogens adhesion by antagonistic strains. Oral microbiology and immunology. 2008;23(1):438.

5. Fine DH, Markowitz K, Fairlie K, Tischio-Bereski D, Ferrendiz J, Furgang D, et al. A consortium of Aggregatibacter actinomycetemcomitans, Streptococcus parasanguinis, and Filifactor alocis is present in sites prior to bone loss in a longitudinal study of localized aggressive periodontitis. Journal of clinical microbiology. 2013;51(9):2850-61.

6. Avila-Campos MJ, Simionato MRL, Cai S, Mayer MPA, De Lorenzo JL, Zelante F. Virulence factors of Actinobacillus actinomycetemcomitans: other putative factors. Pesquisa Odontológica Brasileira. 2000;14(1):05-11.
7. Lima FLd, Farias FFd, Campos PC, Totola $\mathrm{AH}$, Tavares CAP, Costa JEd, et al. Leukotoxic activity of Actinobacillus actinomycetemcomitans isolated from human and non-human primates. Brazilian Journal of Microbiology. 2001;32(3):250-6.

8. Yang HW, Huang YF, Chan Y, Chou MY. Relationship of Actinobacillus actinomycetemcomitans serotypes to periodontal condition: prevalence and proportions in subgingival plaque. European journal of oral sciences. 2005;113(1):28-33.

9. Faveri M, Figueiredo LC, Duarte PM, Mestnik MJ, Mayer MP, Feres M. Microbiological profile of untreated subjects with localized aggressive periodontitis. Journal of clinical periodontology. 2009;36(9):739-49.

10. Sanz M, Quirynen M. Advances in the aetiology of periodontitis. Group A consensus report of the 5th European Workshop in Periodontology. Journal of clinical periodontology. 2005;32 Suppl 6:54-6.

11. Flemmig TF, Sorensen JA, Newman MG, Nachnani S. Gingival enhancement in fixed prosthodontics. Part II: Microbiologic findings. The Journal of prosthetic dentistry. 1991;65(3):36572.

12. Loe H, Theilade E, Jensen SB. Experimental gingivitis in man. The Journal of periodontology. 1965;36:177-87.

13. Newman MG, Socransky SS, Savitt ED, Propas DA, Crawford A. Studies of the microbiology of periodontosis. The Journal of periodontology. 1976;47(7):373-9.

14. Lang NP. Commentary: bacteria play a critical role in the etiology of periodontal disease. The Journal of periodontology. 2014;85(2):211-3.

15. Albandar JM. Aggressive periodontitis: case definition and diagnostic criteria. Periodontology 2000. 2014;65(1):1326. 
16. Klai S, Altenburger M, Spitzmuller B, Anderson A, Hellwig E, Al-Ahmad A Antimicrobial effects of dental luting glass ionomer cements on Streptococcus mutans. TheScientificWorldJournal. 2014;2014:807086.

17. Orstavik D, Hensten-Pettersen A. Antibacterial activity of tooth-colored dental restorative materials. Journal of dental research. 1978;57(2):171-4.

18. Qvist J, Qvist V, Lambjerg-Hansen $H$. Bacteria in cavities beneath intermediary base materials. Scandinavian journal of dental research. 1977;85(5):313-9.
19. Scherer W, Lippman N, Kaim J. Antimicrobial properties of glass-ionomer cements and other restorative materials. Operative dentistry. 1989;14(2):77-81.

20. DeSchepper EJ, White RR, von der Lehr W. Antibacterial effects of glass ionomers. American journal of dentistry. 1989;2(2):51-6.

Recebido em 08/12/2016

Aceito em 18/04/2017
LIMA, TBS

SOUZA, IN

OLIVEIRA RS

GUSMÃO, JMR

GUSMÃO, ICCP

ANTUNES, ANG

ANTIMICROBIAL

ACTIVITY OF DIFFERENT

DENTAL CEMENTS ON

AGGREGATIBACTER

ACTINOMYCETEMCOMITANS

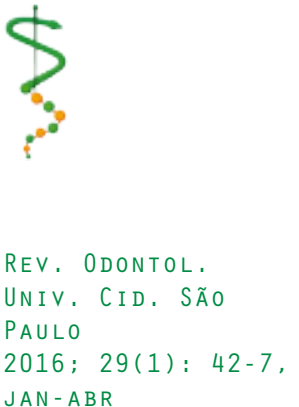

